Copyright (C) 2015 by Academic Publishing House Researcher

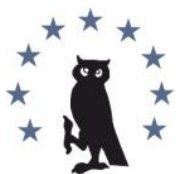

Published in the Russian Federation

Biogeosystem Technique

Has been issued since 2014 .

ISSN: 2409-3386

E-ISSN: $2413-7316$

Vol. 5, Is. 3, pp. 256-266, 2015

DOI: $10.13187 /$ bgt.2015.5.256

www.ejournal19.com

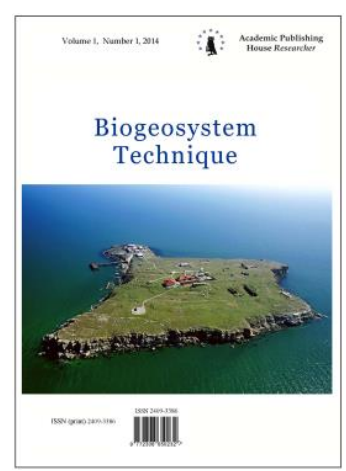

UDC 616:572.1/.4:504.03(8)

\title{
Evolutionary Semantics of Anthropogenesis and Bioethics of Nbic-Technologies
}

${ }^{1}$ Valentin T. Cheshko

2 Yulia V. Kosova

3 Valery I. Glazko

${ }^{1}$ V.N. Karazin Kharkiv national university, Ukraine

sq. Svobody, Kharkiv, 61122

Doctor of Philosophy, PhD, professor, leading researcher

E-mail: cheshko@karazin.ua

${ }^{2}$ Kharkiv National University of Economics named after S. Kuznets, Ukraine

ave. Lenina, 9a, Kharkiv 61166

Lecturer

E-mail: yulia.kosova@gmail.com

3 Russian academy of sciences, Russian Federation

Doctor of Agricultural Sciences, professor

\begin{abstract}
The co-evolutionary concept of tri-modal stable evolutionary strategy (SESH) of Homo sapiens is developed. The concept based on the principle of evolutionary complementarity of anthropogenesis: value of evolutionary risk and evolutionary path of human evolution are defined by descriptive (evolutionary efficiency) and creative-teleological (evolutionary correctness) parameters simultaneously, that cannot be instrumental reduced to others ones. Resulting volume of both parameters define the vectors of human evolution by two gear mechanism - genetic and cultural co-evolution and techno-humanitarian balance. Explanatory model and methodology of evaluation of creatively teleological evolutionary risk component of NBIC technological complex is proposed. The mechanism of influence of each module on the evolution of the two remaining modules of SESH a priori can be twofold: (1) informational co-evolution (direct selective pressure); (2) semantic co-evolution (time-varying semantic code, the compliance of the biological, sociocultural and techno-rationalist adaptive modules of human stable evolutionary strategy). More rapidly evolving autonomous element of the co-evolutionary pair becomes making sense factor for the partner. Semantic co-evolution is the discrete acquisition of adaptive significance of individual alleles by changing socio-cultural types, manifested as an increase in the genetic variability of populations of Homo sapiens, and domesticated species parallel to socio-culturogenesis. The sociocultural landscape leads to drastically difference of direction in biological evolution of Atlantic and East-Slavic ethnicities/civilizations.
\end{abstract}

Keywords: evolutionary semantics, nbic-technologies, co-evolutionary concept. 


\section{Introduction}

In our previous publications [6-8] it was argued that a stable adaptive strategy of Homo sapiens (SESH) is a superposition of three different adaptive informational areas (modules): biological, socio-cultural and technological, which are based on three autonomous processes of generation, replication and implementation of adaptive information - genetic, socio-cultural and symbolic. In this case the third part of SESH is focused equally on an adaptive transformation of the habitat and the bearer of SESH. This concept comes from the ideas of the theory of niche construction. According to the theory epigenetic changes in the genetic information initiate the adaptive change of the conditions of its implementation, and therefore evolutionary landscape selective processes. With regard to the type of modular organization of modular organization of biological adaptations, the set of experimental data on the simultaneous genesis of autonomous adaptive features complexes are obtained $[1,13,35]$. Near concept to our views presented in the monograph of the British sociologist Walter Runciman [31].

\section{Discussion}

Informational and semantic components of the organization of the stable evolutionary strategy of Homo sapiens

The mechanism of the effect of each module on the evolution of the two remaining modules of SESH a priori can be ambivalent:

1. Direct selective pressure, i.e. the change of the adaptive values of the individual features/innovations that are controlled or supported genetically, technologically or through training;

2. Semantic coevolution, i.e. the change in the qualitative or quantitative expression of a particular trait during its implementation as a result of contact with the factors that are the adaptive elements of other SESH modules.

With regard to the gene-cultural coevolution the examples of selective pressure, which consists in changing of gene frequencies in populations with changing socio-cultural environment, were given in this study more than once. Semantic coevolution in this case involves epigenetic modification of the process of realization of genetic information under the influence of sociocultural factors (ethical imperatives, rituals, beliefs, behavioral acts, etc.). All similar factors have the potential to cause psychosomatic response and, over time, to become self-sustaining cycles. In some sense, the mechanisms of interaction of genes and culture of this kind is similar to the placebo effect. The latter, as it is known, is a certain psychosomatic therapeutic action or acts of communication, rituals, physical acts that have no direct pharmaceutical value. According to the recent, though still hypothetical builds, the placebo effect may be due to the changes in the activity of the nerve centers of the brain and activation of the synthesis of various neurotransmitters. Under the action of the latter, the synthesis of specific information molecules (RNA, proteins) either is activated or inhibited [19]. As a result, the functional relationship between behavioral act and physiological response, which is based on the initial psychological pre disposition, is established. Introduced by the authors of the cited work, the concept of "placebo" (placebome), in our opinion, can be a particular description of more general phenomenon -- the existence of a common epigenetic intermediate mechanism through which adaptive interaction between sociocultural and biological SESH module is installed. It is important to note that in this way not only co-evolutionary links between genes and elements of culture are formed, but to each of them a certain adaptive value is assigned.

Separation of the category "adaptivity" on two parameters (introduced by us) -- objectivelyspontaneous (evolutionary efficiency) and subjective-teleological (evolutionary correctness) allows, in our view, to transfer the semantic concept of co-evolution into the sphere of empirical verification. According to the views of its author (S. D. Cousins) the integrity of the co-evolutionary binary opposition of genes-culture is supported by the informational correlations as well as semantic correspondences [11, p. 160-191]. If in the first (informational) aspect the co-evolutionary connection between two areas (modules in our terminology) of adaptive information is provided by the correspondences between informational modules (adaptations) that are supported by biological and socio-cultural inheritance, in the second (semantic) aspect we are talking about rules of such conformity. 
In our view, culture is transformed to the selective factor of human evolution and determinate the fixation or elimination of specific fragments of genetic information according to their adaptability or maladaptive in the socio-cultural environment. Its (culture) evolutionary importance is much higher the powerful selective incentives by the proper environmental landscape. In fact, it gives the impression of "decay" of biological form of adaptation in human evolution [28].

However, the set of possible mechanisms of gene-culture coevolution is not exhausted. Selective pressure on the gene pool of a man having two effects [28, p. 406], that diagnosed and quantified with great methodological difficulties:

(1) Transformation of existing functional significance of genetic variation in accordance to the new adaptive socio-cultural landscape. The essence of this phenomenon is determined by the evolution of the change of function and sometimes is called "exaptation" (to distinguishing from classical adaptation). Exaptation (genetic substrate of evolutionary correctness on our terminology) has an adaptive significance only in the gene-cultural adaptive complex. Potential selective advantage of the genetic and cultural co-adaptations, which then is converted to elemental biological adaptation as part of the integrated genetic and cultural complex (Balduin effect). Phenomenologically the effect creates the impression of a direct genetic pressure on the general vector of cultural evolution and its elementary components, i.e. provide empirical material for genetic and reductionist interpretations of anthropological and ethnogenesis;

(2) The next mechanism of evolutionary cultural and biological interfaces (obviously, humanitarian and technological as well) components of SESH is associated with the cultural inhibition of adaptive modular differentiation of human genome. More rapid cultural and technological adaptive response to problems of survival makes it unnecessary develop a similar adaptive response of elements within genomic clusters, potentially capable of solving the same problem. As a result, firstly, stochastic processes (genetic drift) replace adaptive evolution genetic genome and, secondly, there is a gradual erosion of the components of the adaptive SESH (increase in genetic load).

Therefore, the original co-evolutionary relationship of the culture and genome can be reduced to coadaptation (Darwinian adaptation and exaptation) and disintegration. Since a priori the same types of co-evolutionary relationship applicable to a pair of culture and technology, we can say that the organization of SESH allows two possible scenarios for the future evolution - the growth of system complexity and disintegration. The last scenario involves loss of individual elements of co-evolutionary triad SESH. The ratio of the probability of actualization of both evolutionary scenario is changing with the emergence of each particular genetic, cultural and technological innovation. The magnitude of the resulting effect for the total amount of adaptability SESH determined by the configuration and ranges from zero to one, and therefore requires constant monitoring.

In the framework of the three-module model of SESH the co-evolutionary semantics is interpreted as analysis of the informational code that is being changed in the course of human evolution and providing inter-modular interaction within a coherent system of SESH. Therefore, we are talking about the evolution of the double mutual connotations between elements of biological and socio-cultural, socio-cultural and techno-rationalistic modules. Because of such interactions, that are changing in the course of evolution, a peculiar picture of substantial relations is set: the elements of biological module serve as the substrate basis, providing the substrate foundation for the available pool of socio-cultural adaptations; the elements socio-cultural module serve as a selective filter that quickens or hinders the development of technological innovation.

This transmissional mechanism by which the system of adaptations of one module pre-forms selective topos of another one, S. D. Cousins (as in the center of his attention there is culture as a set of psychological intentions and pre-dispostions) names the intendant [12]. From our point of view, more adequate and lexically neutral in different linguistic context will be used such term as "operator". But in any case the content of this term is revealed through ideal image, that which emerged spontaneously or rationally, of the totality of objective targets that pre-determines selfreplicating (in future) structure of relationships of adaptability/disadaptability of separate elements of each module. This structure further indicates the direction of SESH evolution in whole and its individual elements in particular. 
Another aspect of the realization of functions SESH (co-evolutionary semantics) is a timevarying code of corresponding between members of pairwise co-evolutionary ligaments. (Ssome researchers have used to refer to this phenomenon, the term "semiotic cooptation" or "ecosemiotics" [21, 22]. Those terms are equivalent to (co)evolutionary semantics in our research. Accordingly, we consider as equivalent terms co-evolutionary informatics and semiotic selection, because in the latter case, biological and socio-cultural integration of modules is achieved by mutual selective pressure.

More rapidly evolving autonomous element of the co-evolutionary pair becomes sensecreated factor for the partner. Semantic co-evolution is the discrete act of acquisition of adaptive significance of individual allele's becoause changing of socio-cultural types and manifested as an increase in the genetic variability of populations of Homo sapiens, and domesticated species parallel to socio-culturogenesis.

Indeed, the examples fixation or elimination of certain structural genes in the population under the influence of socio-cultural factors are relatively few. At present, well-founded and reasoned examples of induction by culture- and technogenesis fixing in the human gene pool of the genetic determinants of monogenic or oligogene phenotypic traits are: constant lactase and amylase activity in human ontogenesis [16], sickle-cell anemia m other pathologies, lack of alcohol addiction [14], gay male behavioral activity [3], intention to reduce the emotional tension in interpersonal conflicts [32, 10], the development of the speech center and so on. A priori we can assume only two evolutionary mechanisms through which socio-cultural module SESH involves genetic inadaptability spread in human populations: the acquisition of pathological features of the group as a result of the adaptive value of the induced culture lifestyle changes (sickle-cell anemia and other tropical gematopaties in irrigated agriculture areas - as a result of increased morbidity from malaria), and the transformation of highly adaptive to abnormal biological characteristics, for the same reasons (Crohn's disease, psoriasis, resulting giper-reactivity immune system) for the same reasons [15].

However, the correlation between the levels and patterns of genetic polymorphism and epysociocultural type overlap no doubt parallel to the change of socio-cultural types [4]. Moreover, pattern of the impact of culture on the organization of the genome is distributed from actual human genome to the genomes of "cultivated" (domesticated) species, whose existence and now depend on the evolution of man. The genome of these species formed sub-genome providing communication with biological evolution as an evolving system of social and cultural predisposition [17, p. 30].

According to paleogenetic data, induced by culture change genetic frequencies become noticeable during the so-called Neolithic revolution - the transition to agriculture and animal husbandry [30]. As a result of the Neolithic revolution in evolutionary mechanisms of anthropogenesis prevailed two new fundamental attribute - "conscious" (techno-rationalist) adaptatiogenesis components and adaptively significant increase in the size of social communities at the expense of not only population growth but the intergroup integration processes too [18, p. 65-67].

So, a specified model of the three-module model of organization of SESH includes (1) three informational modules (bio-, cultural - and techno-rationalistic), each one with its own system of generating, encoding and inheritance of adaptive information and (2) three semantic operator (transmission mechanism) that connect the modules to each other, and semantic connotations of the members of the co-evolutionary bundle vary in time.

In socio-humanitarian and natural-science conceptual and categorical framework of evolutionary theory, meta-semantic compliance of the categories of paradigmatic significance in which the system of objective interests and evolutionary correctness - systems of values corresponds to the evolutionary efficiency is established. Thus two pairs of categories provide the intersection of socio-prescriptive and descriptive parts of the transdisciplinary theory of anthropogenesis (due to overlapping of their content). Configuration of semantic code is determined by the system of value priorities and the system of rationally justified interests (technorationalistic module). A priori we can assume that the semantic code of inter-module interaction is going through periods of relative stability followed by periods of uneven rearrangement initiated by the reconstruction of the value system (socio-cultural module) or objective knowledge and its 
practical application (techno-rationalist module. (Change of the semantic code that defines the correspondence between the statuses of the individual modules, by definition, is initiated by the module, the rate of evolution of which is greater.) Such restructuring of the semantic connotations is fraught with sharp adaptive intensification of conflicts by increasing the size of the evolutionary load and evolutionary risk. The size of the risk reaches an existential level, when the vectors of evolutionary efficiency and evolutionary correctness are incompatible (antiparallel).

Therefore, semantic analysis can be applied equally to all co-evolutionary cycles (operators) inside SESH - to gene-cultural co-evolution, and the techno-humanitarian balance, and to the forming cycle of techno-biological transformations. The study of the semantic differences between the elements of binary techno-cultural and genetic cultural bunches serves as the basis for defining the current vector of the evolution and size of the current evolutionary risk of Homo sapiens.

Rational and technogenesis as the form and the mechanism of adaptation supposes availability of a cognitive (semantic) code. Its unique feature is the hegemony of random system of correlative correspondences between thoughts (interpretants), serving as promoters for the adaptively important behavioral acts, and as appropriate symbols. The availability of interpretants joins the mechanisms of functioning of the socio-cultural and rationalistic part of SESH. The difference between them consists in random coding system of adaptive behavioral acts that is capable to change physical, social or mental reality by increasing or reducing individual and/or group adaptability of their carriers. This idea is not something fundamentally new. In 1987, for example, in one of the articles it was claimed that the basis for the evolutionary uniqueness of man is the ability to conceptually abstracted from the situations modeling of the actions necessary to achieve the objectives that correlate with adaptation. The ability, speaking the language of the theory of cognition, to create the idealistic rationalistic models of objective reality, is called the "cognitive niche" [36, p. 209]. Given argumentation of the specific (not to say uniqueness) of SESH can be formulated as a postulate about rationalization of the process of adaptogenesis of Homo sapiens and other hominids. Metaphysical statement about teleological anthropogenesis with the emergence of the technologies of controlled evolution (NBIC-technological complex, convergent technologies, High Hume technology in a broad metaphorical meaning which doesn't change the essence) became quite compatible with the concept of the objective nature of the evolutionary process. Moreover, the observation of the simultaneous existence of several conjugate evolving systems of generation and inheritance of adaptive traits, on the assumption of the inequality of the speeds of adaptaciogenesis in each of them, makes teleologicy quite "natural".

Co-evolutionary semantics of evolutionary risk

As a result, the second aspect of the implementation of the SESH functions is constituted - it is semantic aspect. Co-evolutionary semantics is a time-varying code of correspondence between members of pairwise co-evolutional bunches.

The role of the operator that sets the rules of the biological and socio-cultural, socio-cultural and rational-technological, rational-technological and biological informational areas performs either the system of objectified interests (praxeologically oriented knowledge), or the system of subjective values (psychological pre-dispositions). Replication of the interests is carried out in the framework of the rational-technological module based on the mechanisms of symbolic inheritance, value priorities - within the framework of socio-cultural module and, accordingly, socio-cultural inheritance (cultural tradition). If the main "purpose" of interests is material survival of the carriers of SESH (evolutionary efficiency), then the content of the same parameter (evolutionary correctness) of values is determined by their ability to ensure self-identity preservation.

Such organization is able to spontaneous increase of system complexity, and at different stages of socio-anthropological genesis the role of the leader is taken by some of its components. Approximately 350-400 years ago as a result of transmutation of the socio-cultural component of the SAS the technogenic civilization emerged, the main feature of which is a permanent extension of the "socio-ecological niches" (sphere of control) of Homo sapiens and parallel escalation of risks of the anthropo-technological impact

Accordingly, to Bernard Crespi [13], share associated with hereditary diseases structural genes or certain haplotypes demonstrated positive selection pressure during last 10 thousand years of human evolution for 17-21 \% for neurological disorders and 15-21 \% for other diseases etiology. 
In the control group, (pool of genes in that positive selection during the relevant period was not observed) analogous index fluctuated between 21-25\%.

Postponed effects of genetic conflicts within biological module of SESH and between biological module on the one hand, and technological and socio-cultural modules on the other stretched out on millenniums. For example, changing a habitual way of eating (diet), that was peculiar to man until the Neolithic revolution, caused a modification in the metabolism of lipids, proteins, carbohydrates that emerged in late - and post reproductive age. These effects, therefore, are closed for the effect of the biological forms of natural selection. As it is supposed now, the increase of frequency of cardiovascular (stroke, heart attack, atherosclerosis), oncological pathology, diabetes of type II, etc. are linked exactly to them. In addition to this, there is imbalance in the development of the sexual sphere, manifested in the discrepancy between the timing of the start of the menstrual cycle and other components of puberty of women. All this is a clear trend of size of the evolutionary risks inherent in a Western type of technological civilization. (The details of these problems are outlined in a recent book by the Swedish nutritionist, adept of the evolutionary medicine Stefan Lindeberg [25]; the coupled evolution of the human genome and culture, causing to the genesis of the "diseases of civilization" are also examined in the book by Daniel Lieberman [24]. Both researchers consider the transition to a non fruit diet, twhhat was determined by sociocultural heredity, as a systemic factor that reformatted the structure and meaning of the relationship between biological and behavioral, and then non-genetical adaptations. Later, using the arguments of these researchers we will try to justify the semantic concept of co-evolution as an explanatory model of the transmission mechanism between SESH modules.)

The rating of reduction of adaptability according to this indicator on reaching a certain threshold zone of values or as a result of the same threshold of changes of ecological and cultural environment is cable of fast growth, twhat demands the immediate adaptive response (solving of the problem of survival). Such leap, in fact, is the actualization of evolutionary risk. One of the symptoms of this updating is a systemic effect - distribution beyond the bounds of the initial module to the other components of SESH. So the above-mentioned diseases of Western civilization during the past twentieth century was transformed from a purely medical (i.e. directly related to the biological module) problems on the areas that guide the evolution of socio-cultural module (including the economy).

The evolutionary risk reaches the maximum size in case of antiparallelly of dynamics of changes in evolutionary efficiency and evolutionary correctness, when the characteristic size of risk very quickly crosses the boundaries of "physical" sense (Rint>1). Reaching this point means irreversible semantic destruction (destruction of the system of value priorities, the central core of which is the concept of humanity and human nature).

It seems logical to make two clarifications. The periods of abrupt increasing of the size of evolutionary risk, obviously, are coherent to the periods of "scientific-technological revolution" and to the periods of radical reconstructions of value systems prevailing in the society. Exactly then the structure of the co-evolution connections between the elementary adaptations of different modules of SESH and actually adaptive value of each element is destabilized and prone to unpredictable stochastic fluctuations.

The system of value priorities dominant in society has several-level structure - the individual (unconditional) interests, group (conventional) requirements, an abstract (universal) values [18; 22]. Here, primarily in the field of group norms and predispostions regarding specific attributes of humanization/dehumanization, relatively rapid reconstructions radically changing the semantic of relations between cultural module and biological and techno-national ones are possible [9]. As a result, the adaptive landscape, in which evolution of, for example, biological module (adaptive significance of individual elements) takes place, is quickly reformatted. As an example we can take a radical revision of value priorities on group and individual level towards traditional and nontraditional sexual orientation in the Western mentality in 1970s-2015s. Universal values are practically not involved in this, not-yet-finished process of transformation of socio-cultural and psychological predispostion.

Thus, we can assume that out of three levels of values priority (and their corresponding sociocultural predispostions) individual interests, group norms and universal values, the most susceptible to evolutionary transformations are the group norms. 
More stable are the individual interests (as most closely associated with the vital needs, determined by biological module) and universal values (as the most abstract, distant from objective reality and close to the rationalistic module). However, the effect of perturbations of group norms - attributes of humanization/dehumanization -- diffuses by the means of evolutionary semantic transmission mechanism on the biological module, destroying, in its turn, the rules, of semantic matching of this module with two remaining. Because of this secondary effect the elements of the biological module of SESH are distributed first to the system of objective "interests" and then to other levels of the socio-cultural module. The fixation of a particular set of group norms and then the review of universal values, as the latter are projective reflection of the group norms and individual interests, are taking place.

So, a certain part of the biological adaptation in a new socio-cultural context becomes the elements of genetic load (inadaptive or selectively neutral), and, conversely, a part of harmful or selectively neutral components of the genome are acquire adaptive value. With regard to the technological innovation, together they are definitely aimed at the fragmentation of the biological adaptive complex.

If the value of scientific and technological revolutions (shifts of paradigms) has been investigated (suffice its to recall the classical monograph of Thomas Kuhn of 1962), the evolutionary significance of social and cultural transformation begins to clear up only now. Meanwhile, the socio-cultural inheritance is also able to radical rearrangements of its structure and composition. It takes only to mention the radical change of predispostion regarding sexuality that has occurred in the Western mentality over the past half century. Relative independence of each module is an additional complicating circumstance, as the result of this independence, for example, "macromutation" of the system of cultural and psychological predispostions aimed primarily at preserving the structural distribution of subcultures within a given civilization type, and only then, at the selection of relevant biological elements of SESH module.

However, in the conditions of the relative balance of genetic-cultural ("Gene-culture coevolution".) and techno-cultural ("Techno humanitarian balance".) co-evolutional semantics and the lack of direct preformative impact of techno-rationalist SESH module on the two left (biological and sociocultural), the configuration of the entire system also did not allow an uncontrolled jump of risk to the existential level.

In our previous works we have already formulated the terms of such semantic stability in terms of socio-humanitarian knowledge: the core of the mentality of the West is the desire of a person to a certain maximum ideal ("Per aspera ad astra - through the thorns to the stars"). It is complemented by the second pivotal construction, paralyzing and, simultaneously, challenging the limits of this ideal ("Ad imaginem suam ad imaginem Dei - In the image and likeness of God") and focuses on the chosen-ness, the absolute priority of the uniqueness of the human person ("Unus ex nobis - One of us" as God says about Adam). Thus the actualization of the desire to bring together the world as it is and the world as it should be gains the character of the movement towards the absolute, the ultimate goal ("the omega point", as named by Teilhard de Chardin) [7, c. 11, 506].

In objectified, dismissed from the metaphors form the same argument boils down to the statement that one of the basic predispostion of mentality of industrial civilization in its Western form, is a trend to release the social roles and social status of an individual from the preformation by conditions of his biological substrate (the genome) as a criterion of social (and evolutionary) progress. This trend, in turn, is balanced by the irrational fear of a possible intervention in the human psyche from the outside that violate the free will of the individual and forcing him to act against his "human nature". This trend can be traced back at least to biblical times and legends about werewolves and vampires, through the Gothic novels of the eighteenth century to modern thrillers and science fiction of the most recent years.

The sociocultural system of counterweights, ensuring the self-identity of Homo sapiens, turned out to be very stable, but only until the birth of the technologies of driven evolution, when ontological antinomy Evolution versus Intelligent Design was finally overcome. As a result, the restrictions arising from the limited technological means for reality transformation turned to be overcome, at least in potentio. The only built-in inside SESH stabilizer of the current of global evolutionary process remains the semantic code of humanization/dehumanization, which in itself allows significant stochastic fluctuations, and is open to technological interventions and therefore needs continuous monitoring. 
With the emergence of High-Hume technologies the level of risk is reached the existential level of significance. At this existential level of technological risk means by definition evolutionary risk, because it leads to the genesis of the possibility of the extinction of mankind as a species (but not necessarily intelligent life and the noosphere).

\section{Conclusion}

It seems inevitable that, because of the modular-hierarchical organization SESH in conjunction with multiple autonomous systems and the generation of adaptive replication of information with respect to the formation of long-term evolutionary trends reduce the adaptability of such a module by increasing adaptability of another module. This conclusion is supported by the arguments of the theory of programming and computer science [2;23]. This trend in the present study, as mentioned above, will be called the evolutionary risk.

In the era when evolution itself becomes a subject of rational control and/or manipulation, it is necessary to calculate when making a projection and determining the amount of innovative risk those features of social response to scientific and technological development, which stems from the substantial foundations of human consciousness and culture and are the result of the previous biosocial evolution.

Modification of techno-cultural balance, which is an adaptive response of the SESH sociocultural component to the processes described above, led to the transformation of classical science to its postacademic form. In the framework of the same global-evolutionary transformation we have to consider the emergence of bioethics as one of the varieties of contemporary (trans-disciplinary) scientific concept, which combines the features of the Humanities, classical scientific theory and social utopia. Not so long ago E. Kunin, was very observant when diagnosed a curious feature of the explanatory models of modern evolutionary biology: all of them are narratives with more or less, but always available portion of teleology. Consciously or not they have, in explicit or implicit form, logical constructs such as "arise for...", the language of these narratives (though it contradicts the methodology of classical not modern, transdisciplinary science) best suits to the describe evolutionary processes and phenomena, and the creation of hypotheses which can be verified by experience [21].

Especially it is true for the modern phase of the evolution of SESH, which is characterized by a universal process of rationalization and technologization of the course of evolution. The introduced concept of evolutionary risk, in which objective and scientific (evolutionary efficiency) and subjective and humanitarian (evolutionary correctness) criteria of the value of this parameter combines, in accordance with the principle of subsidiarity serves as the example of such an explanatory model.

The problem of evolutionary risk and its components is coming within the conceptual field of anthropic principle, since one of the parameters of the equation of the doomsday simultaneously becomes not only a global constant that is crucial to the human genesis in the Universe, but also a derivative from the characteristics of sociocultural and biological evolution. It did not fail to specify One of the pioneers of the anthropic principle Brandon Carter didn't fail to point at this fact [5].

In 1960 Heinz von Foerster has formulated the law of hyperbolic growth in the number of Homo sapiens, also known under the non-academic title "Doomsday Equation" [34]. In accordance with the Foerster's equation, the population growth for approximately the last 10 thousand years, obeys an equation of the hyperbola, i.e. increases with increasing acceleration and about up to 2025 will be infinite, i.e. loses physical meaning. It will mean the end of the evolutionary history of Homo sapiens, although not necessarily imply the death of intelligent life at all. Rather, it means the passage of a certain point of the evolutionary singularity, the achievement of the value of evolutionary risk close to unit.

In the Foerster's equation there is the parameter $\mathrm{T}^{*}$, which had been empirically calculated by the authors and according to them was about 2.1011. Brandon Carter in the work cited above [5] considers this option as a member of the pool of world constants that determined the emergence of human and the formation of the laws of nature of civilization that are able to reflect. In his understanding this value is a function of the amount of information (1010 bits) contained in the human genome and the duration of existence of one generation (20 years). By reducing this parameter below the threshold value, the transition from biological to sociocultural, and then technological phases of anthropogenesis (phases II-III in our periodization of the evolution of SESH) becomes impossible. 
And phenomenological interpretation and explanatory model of the Foerster's Doomsday Equation quite consistent with the notion about the organization of SESH and the mechanisms of formation of evolutionary risk, advocated in the present study.

On the one hand, the population growth increases the frequency of techno-rationalist and sociocultural innovations/adaptations and the speed of their distribution in the population, which in accordance with Lamarck's module flows through contagious mechanism. Thereby the ecological niches available for the development of Homo sapiens are expanded, and the conditions for further acceleration of population growth are created [22].

On the other hand, the integrity of the structure three-module SESH means the availability of some inter-module communicational correspondences between the elements of biological and sociocultural modules of the co-evolutional semantics. Even under the condition of the ambiguity of semantic connections between modules with exceeding of a certain threshold in the number of adaptive socio-cultural elements in comparison with the pool of biologically determined signs, that are comparable to them, the efficiency of genesis of adaptation decreeases sharply. Externally it is manifested in the accumulation of genetic and cultural imbalances, inconsistencies between the demands of the sociocultural environment and psycho-physiological capabilities of the organism (evolutional load). In the first approximation, the threshold, beyond which the area of the fracture of the curve of population growth begins, will be attainment of the volume of adaptive information that is replicated with the help of socio-cultural inheritance, the value comparable with the volume of information accumulated in the genome. This situation has two fundamental but alternative evolutionary solutions.

The first ("hard") decision means the technologization of biological evolution of human, i.e. the improvement (enhancement) of Homo sapiens through genetic engineering, etc. technologies, resulting, as already mentioned, in the completion of the evolutionary history of humanity (the loss of self-identity of generations of intellect carrier).

"Soft" solution involves the creation of a radically transformed version of the evolutionary semantics for regulating the flow of gene-cultural co-evolution and techno-humanitarian balance. The newly established co-evolutionary semantics should provide the best match of the biological and techno-rationalistic modules to the so-called universal value priorities, preserving the self-identity of the carriers of the mind.

This final observation, in turn, determines civilizational and evolutionary function of bioethics. Bioethics is largely methodological one. In other words, it is a metatheory, which, we hope, can serve as a stabilizer for the system of attributes-identifiers of human self-identity, as well as for the system of cultural-mental predispostions formed on their basis. This system maintains the existence of the current version of evolutionary semantics NBIC-technological complex within the "universal values", ensuring the preservation of humanity in the process of permanent development of technologies, directed to the subject of the evolutionary process.

\section{References:}

1. Applied Evolutionary Anthropology. Darwinian Approaches to Contemporary World Issues. N.Y.; Heidelberg; Dordrecht; L.: Springer, 2014. P. 299.

2. Banzhaf W. Genetic Programming and Emergence // Genet Program Evolvable Mach. 2014. Vol. 15, No 1. P.63-73

3. Barthes J., Godelle B., Raymond M. Human social stratification and hypergyny: toward an understanding of male homosexual preference // Evolution and Human Behavior. 2013. Vol. 34. P. 155-163.

4. Borinskaya S. A., Yankovsky N. K. Combination genetic and humanitarian (crosscultural) methods for identifying human genes involved in the process of adaptation to the evolutionary new environmental factors//Genetics. 2015. Vol. 51, No. 4. P. 479-490. (In Russian)

5. Carter B. Hominid evolution: genetics versus memetics // Intern. Journ. Astrobiol. 2012. Vol. 11, No 1. P. 3-13.

6. Cheshko V.T., Ivanitskaya L. V., Kosova Y. V. Configuration of Stable Evolutionary Strategy of Homo Sapiens and Evolutionary Risks of Technological Civilization (the Conceptual Model Essay) // Biogeosyst. Tech., 2014, Vol.1, № 1. P. 58-69.

7. Cheshko V.T. Stable adaptive strategy of Homo sapiens: Monograph. Kharkov: Publ.House "INZHEK", 2012. 596 p. (In Russian) 
8. Cheshko V.T., Ivanitskaya L.V., Glazko V.I. Evolutionary Risk of HIGH HUME technologies. Article 1, 2 // Integrat. Anthropology. 2014. № 2. P. 4-14; 2015. № 1. P. 4-15. (In Russian)

9. Cheshko V.T., Peredyadenko A.S. Descriptive and socio-cultural (ethical) components of the structure of evolutionary risks of genetic engineering technological complex // Ecology Herald, 2015. № 1. P. 64-72. (In Russian)

10. Chiao Joan Y., Blizinsky Katherine D. Culture-gene coevolution of individualismcollectivism and the serotonin transporter gene // Proc. Royal. Soc. 2010. Ser.B. Vol. 277. P. 529-537.

11. Cousins S.D. A semiotic approach to mind and culture // Culture \& Psychology. 2012. Vol.18, No 2. P. 149-166.

12. Cousins S.D. The semiotic coevolution of mind and culture // Culture \& Psychology. 2014. Vol. 20, No 2. P. 160-191.

13. Crespi B. J. The origins and evolution of genetic disease risk in modern humans // Ann. N.Y. Acad. Sci. 2010. Vol. 1206. P.80-109

14. Dudley R. The drunken monkey: why we drink and abuse alcohol / R. Dudley. Berkeley; Los Angeles; L.: University of California Press, 2014. 179 p.

15. The Evolution and Functional Impact of Human Deletion Variants Shared with Archaic Hominin Genomes / Yen-LungLin, P.Pavlidis, E. Karakoc, J.Ajay, O. Gokcumen http://mbe.oxfordjournals.org/content/early/2015/01/22/molbev.msu405 - aff-1 // MolBiolEvol 2015. doi:10.1093/molbev/msu405

16. The evolution of lactase persistence in Europe. A synthesis of archaeological and genetic evidence / M. Leonardi, P. Gerbault, M. G. T., J. Burger // International Dairy Journal. 2012. Vol. 22. P. 88-97.

17. Glazko V.I. Shaping and microevolution: livestock formation, metabolomics, SubGenome // Farm animals. 2014. № 1. P. 20-32

18. Grinin LE The state and the historical process. The era of state formation: the overall context of social evolution in the formation of the state. M.: Book Kom, 2007. 272 p. (In Russian)

19. Hall K.T., Loscalzo J., Kaptchuk T.J. Genetics and the placebo effect: the placebome // Trends in Molecular Medicine. 2015. P. 1-10 http://dx.doi.org/10.1016/j.molmed.2015.02.009

20. Kohlberg L. Stage and sequence: The cognitive-developmental approach to socialization.

// Handbook of Socialization Theory and Research. Chicago: Ran McNally. 1969. P. 347-480.

21. Koonin E.V. The Logic of Chance: The Nature and Origin of Biological Evolution Nrw Jesey: Person Edcation, 2011. 528 p.

22. Kapitza S.P. Global population blowup and after the demographic revolution and information society. Hamburg: Global Marshall Plan Initiative, 2006. 272 p.

23. Leier A. Emergence in simulated evolution // Genet Program Evolvable Mach. 2014. Vol.15. No 1. P. 79-81

24. Lieberman D. The story of the human body: evolution, health, and disease. N.Y.: Pantheon.2013. $480 \mathrm{p}$

25. Lindeberg S. Food and Western Disease: Health and nutrition from an evolutionary perspective. Oxford: Wiley-Blackwell, 2010. 370 p.

26. Maran T., Kleisner K. Towards an Evolutionary Biosemiotics: Semiotic Selection and Semiotic Co-option // Biosemiotics. 2010, Vol. 3, No 2. P 189-200

27. Maran, T., Kull, K. Ecosemiotics: main principles and current developments // Geografiska Annaler: Series B, Human Geography 2014. Vol. 96. No 1. P. 41-50

28. Milbrath C. Socio-cultural selection and the sculpting of the human genome: Cultures'directional forces on evolution and development, New Ideas in Psychology. 2013. Vol.31, No 3. P. 390-406.

29. Neural Correlates of Post-Conventional Moral Reasoning: A Voxel-Based Morphometry

Study / K. Prehn, M. Korczykowski, H. Rao, Zhuo Fang, J.A. Detre, D.C. Robertson // PLoS One. 2015. Vol. 3, No 10(6). Publ.eo122914. DOI: 10.1371/journal.pone.0122914.

30. O’Brien M. J., Laland K. N. Genes, Culture, and Agriculture: An Example of Human Niche Construction // Current Anthropology. 2012. Vol. 53, No. 4. P. 434-470.

31. Runciman W. G. The Theory of Cultural and Social Selection- Cambridge: Cambridge University Press. 2009. P. 257. 
32. Schinka J.A., Letsch E.A., Crawford F.C. DRD4 and Novelty Seeking: Results of MetaAnalyses // Amer. Journ. of Med. Genet. 2002. Vol. 114. P. 643-648.

33. Tooby J., De Vore I. The reconstruction of hominid behavioral evolution through strategic modelling // The evolution of human behavior: primate models. Ed. W. G. Kinzey, N.Y.: SUNY Press. 1987. P. 183-227.

34. Von Foerster H., Mora P. M., Lawrence L.W.Doomsday: Friday, 13 November, A.D. 2026 // Science 1960. Vol. 132, No. 3436. P. 1291-1295.

35. Wells J.C.K. Ecological Volatility and Human Evolution: A Novel Perspective on Life History and Reproductive Strategy // Evolutionary Anthropology. 2012. Vol. 21. P. 277-288.

36. Whiten A., Erdal D. The human socio-cognitive niche and its evolutionary origins // Phil. Trans. Roy. Soc. 2012. Ser. B. Vol. 367. P. 2119-2129.

Удк 616:572.1/.4:504.03(8)

\title{
Эволюционная семантика антропогенеза и биоэтика nbic-технологий
}

\author{
${ }^{1}$ Валентин Федорович Чешко \\ 2 Юлия Викторовна Косова \\ 3 Валерий Иванович Глазко
}

${ }^{1}$ Харьковский национальный университет им. В.Н. Каразина, Украина
пл. Свободы, 4, Харьков 61022
Доктор философских наук, кандидат биолологических наук, професор, ведуший научный
сотрудник, акад. РАЕН
E-mail: cheshko@karazin.ua
${ }^{2}$ Харьковский национальный экономический университет им. С. Кузнеца, Украина
просп. Ленина, 9А, Харьков 61166
Преподаватель
E-mail: уulia.kosova@gmail.com
3 Российская академия наук, Российская Федерация
Доктор сельскохозяйственных наук, профессор, академик РАН (иностр. член)

Аннотация. Разрабатывается коэволюционная концепция трехмодульной стабильной эволюционной стратегии Homo sapiens, которая основана на принципе эволюционной дополнительности: величина эволюционного риска и эволюционная траектория антропогенеза определяется одновременно двумя параметрами - спонтанно-дескриптивным (эволюционная эффективность) и креативно-телеологическим (эволюционная корректность), которые невозможно инструментально редуцировать друг к другу. Соотносительные значения обоих параметров определяют векторы биологической, социокультурной и техно рационалистической эволюции человека через два передаточных механизма - генно-культурную коэволюцию и техно гуманитарный баланс. Предлагается объяснительная модель и методология расчета креативно-телеологического компонента эволюционного риска NBIC технологического комплекса. Механизм влияния каждого модуля на эволюцию двух оставшихся модулей $\mathrm{CACH}$ a priori может быть двойственным: (1) информационная коэволюция (Прямое селективное давление) и (2) семантическая коэволюция (изменяющийся во времени семантический код, обеспечивающий соответствие биологического, социокультурного и технорационалистического адаптивных модулей). Семантическая коэволюция является дискретным приобретением адаптивного значения отдельными аллелями при смене социокультурного типа и проявляется как возрастание генетической вариабельности популяции человека и одомашненных видов параллельно социо-культурогенезу. Предполагается существование радикальных различий в социо-культурном эволюционном ландшафте Атлантического и Восточно-славянского этносов/цивилизаций.

Ключевые слова: эволюционная семантика, nbic-технологии, коэволюционная концепция. 